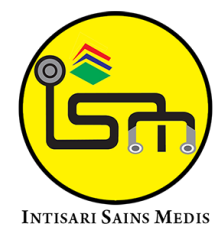

Published by Intisari Sains Medis

\title{
Hubungan antara ekspresi BRAF V600E dengan metastasis dan derajat diferensiasi pada adenokarsinoma kolorektal
}

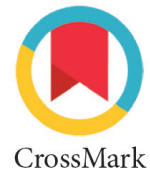

CrossMark

\begin{abstract}
Ni Kadek Ayu Maya Damayanti ${ }^{1 *}$, Ni Wayan Winarti', Ni Putu Sriwidyani', Luh Putu lin Indrayani Maker', Herman Saputra', I Made Muliarta²
\end{abstract}

\section{ABSTRACT}

Background: Colorectal carcinoma is a malignant epithelial tumor of the large bowel that occurs due to extrinsic and intrinsic factors. BRAF V600E gene mutation was found in about $10-15 \%$ of colorectal carcinoma. This mutation was associated with aggressive biologic behaviors, metastasis and lesser responsiveness to EGFR inhibitors therapy. This study aims to determine the association between BRAF V600E expression with metastasis and the degree of differentiation of colorectal adenocarcinoma.

Methods: This cross sectional study involved 43 samples of adenocarcinoma colorectal patients who had histopathological examinations in the period 20182019. Immunohistochemical were performed to assess the expression of BRAF V600E. This expression was concluded positively if $75 \%$ or more tumor cells showed intense cytoplasmic staining. Data were analyzed using
SPSS version 20 for Windows.

Results: Within 43 colorectal adenocarcinoma cases, it was found 7 cases (16.3\%) had a positive expression of BRAF V600E. This expression was found in metastasis cases (7/25), not found in cases without metastasis (0/18). There was an association between BRAF V600E expression and metastasis $(p=0.014)$. The positive expressions of BRAF V600E were only found in low-grade differentiation (7/35 cases), were not found in high-grade differentiation (0/8 cases), and no association between BRAF V600E mutation and the degree of differentiation $(p=0.167)$.

Conclusion: There was an association between BRAF V600E expression and metastasis of colorectal adenocarcinoma. There was no significant association between BRAF V600E expression and the degree of differentiation of colorectal adenocarcinoma.

Keywords: Colorectal Carcinoma, BRAF V600E Expression, Metastasis, Degree of Differentiation.

Cite This Article: Damayanti, N.K.A.M., Winarti, N.W., Sriwidyani, N.P., Maker, L.P.I.I., Saputra, H., Muliarta, I.M. 2021. Hubungan antara ekspresi BRAF V600E dengan metastasis dan derajat diferensiasi pada adenokarsinoma kolorektal. Intisari Sains Medis 12(2): 524-529. D01: 10.15562/ism.v12i2.1045

'Departemen Patologi Anatomi, Fakultas Kedokteran, Universitas Udayana, RSUP Sanglah, Bali, Indonesia;

${ }^{2}$ Departemen Fisiologi, Fakultas Kedokteran, Universitas Udayana, Bali, Indonesia;

\section{*Korespondensi:}

Ni Kadek Ayu Maya Damayanti;

Departemen Patologi Anatomi, Fakultas Kedokteran, Universitas Udayana, RSUP Sanglah, Bali, Indonesia; maydyanti3690@gmail.com dinyatakan positif jika $75 \%$ atau lebih sel tumor mununjukkan pulasan sitoplasma dengan intensitas kuat. Data dianalisis dengan SPSS versi 20 untuk Windows.

Hasil: Dari 43 kasus, ditemukan 7 kasus (16,3\%) dengan ekspresi BRAF V600E positif. Ekspresi ini hanya dijumpai pada kasus dengan metastasis ( 7 dari 25 kasus), tidak dijumpai pada kasus tanpa metastasis ( 0 dari 18 kasus). Didapatkan hubungan bermakna antara ekspresi BRAF V600E dengan metastasis $(p=0,014)$. Ekspresi BRAF V600E positif hanya ditemukan pada kasus derajat diferensiasi rendah (7 dari 35 kasus), tidak ditemukan pada derajat tinggi (0 dari 8 kasus), dan hubungan tersebut tidak bermakna secara statistik $(p=0,167)$.

Kesimpulan: Terdapat hubungan antara ekspresi BRAF V600E dengan metastasis pada adenokarsinoma 
kolorektal. Tidak terdapat hubungan antara ekspresi adenokarsinoma kolorektal. BRAF V600E dengan derajat diferensiasi pada

Kata kunci: Karsinoma Kolorektal, Ekspresi BRAF V600E, Metastasis, Derajat Diferensiasi. Sitasi Artikel ini: Damayanti, N.K.A.M., Winarti, N.W., Sriwidyani, N.P., Maker, L.P.I.I., Saputra, H., Muliarta, I.M. 2021. Hubungan antara ekspresi BRAF V600E dengan metastasis dan derajat diferensiasi pada adenokarsinoma kolorektal. Intisari Sains Medis 12(2): 524-529. D0l: 10.15562/ism.v12i2.1045

\section{PENDAHULUAN}

Kanker kolorektal (KKR) mewakili sekelompok penyakit heterogen molekuler. Biomarker molekuler memegang peranan penting untuk memahami heterogenitas biologis KKR dan untuk mengklasifikasikan KKR menjadi subtipe yang dapat digunakan untuk memprediksi prognosis, respon pengobatan, dan risiko kekambuhan. Jalur molekuler utama ini berpotensi dalam pemilihan terapi yang akan diberikan sesuai dengan kebutuhan penderita KKR. ${ }^{1}$ Kanker kolorektal menduduki peringkat keempat sebagai kanker paling sering terjadi di seluruh dunia dan merupakan penyebab kematian terkait kanker tersering kedua. ${ }^{2}$ Kanker ini menduduki peringkat keempat sebagai penyebab kematian terkait kanker yang paling sering di seluruh dunia. Insiden kanker kolon di Indonesia sebesar 8,6\% dengan angka mortalitas 3,84\%. ${ }^{3,4}$ Angka ini membuat KKR menempati peringkat keempat sebagai kanker dengan insiden tertinggi di Indonesia. ${ }^{3-5}$ Mutasi gen BRAF dijumpai pada satu dari sepuluh pasien yang mengalami KKR. Pasien dengan mutasi BRAF masih memiliki prognosis yang buruk, dengan median survival kurang dari 12 bulan. ${ }^{6}$ Studi Ritterhouse LL dan Barletta JA pada tahun 2015 menunjukkan mutasi BRAF terjadi pada $10-15 \%$ pasien KKR. ${ }^{7}$ Mutasi BRAF pada metastasis KKR juga berhubungan dengan overall survival yang buruk. ${ }^{7,8}$ Pasien yang mengalami diferensiasi buruk memiliki insiden yang lebih tinggi untuk terjadinya mutasi BRAF V600E dibandingkan dengan KKR diferensiasi baik/sedang $(7,77 \%$ dengan $2,92 \%, P=$ $0,04){ }^{9}$ Studi yang dilakukan oleh Wang $\mathrm{X}$ et al., pada tahun 2017 dengan jumlah 63 penderita KKR dengan mutasi BRAF menunjukkan tumor dengan mutasi BRAF V600E lebih sering berlokasi pada kolon kanan (42,9\%), hampir setengah pasien mengalami metastasis peritoneum $(41,3 \%)$, cenderung bermetastasis ke kelenjar getah bening yang jauh $(79,4 \%){ }^{10}$

Mutasi pada BRAF juga berguna dalam memprediksi efikasi terapi karsinoma kolorektal yang menggunakan inhibitor Epidermal Growth Factor Receptor (EGFR) berupa Cetuximab atau panitumumab. Hal ini dikarenakan mutasi BRAF menyebabkan aktivasi konsekutif dari kaskade sinyal sehingga terjadi proliferasi sel yang terus-menerus dan pertumbuhan tumor yang tidak terkontrol. Efek tersebut terjadi secara downstream pada reseptor EGFR, sehingga membuat tumor ini resisten terhadap anti-EGFR. ${ }^{11,12}$

Derajat diferensiasi pada KKR berdasarkan pembentukan kelenjar dan komponen diferensiasi. Derajat diferensiasi rendah untuk diferensiasi baik hingga sedang dan derajat diferensiasi tinggi. ${ }^{13,14}$ Tumor dengan derajat diferensiasi tinggi (diferensiasi buruk) berhubungan dengan peningkatan nodal yang diinfitrasi sel tumor dan metastasis jauh, serta prognosis yang lebih buruk. ${ }^{15}$

Penting bagi para klinisi untuk dapat mengetahui status molekuler pasien KKR. Skrining dan deteksi dini memungkinkan para praktisi kesehatan untuk memahami aspek genetik dan epigenetik dalam tumorgenesis KKR sehingga morbiditas dan mortalitas dapat ditekan. $^{12}$ Berdasarkan latar belakang di atas, penelitian ini dilakukan untuk menilai hubungan antara ekpresi BRAF V600E dengan metastasis dan derajat diferensiasi adenokarsinoma kolorektal di RSUP Sanglah.

\section{METODE}

Penelitian ini merupakan penelitian observasional analitik dengan rancangan yang digunakan adalah studi potong lintang. Penelitian dilakukan di
Laboratorium Patologi Anatomi Fakultas Kedokteran Universitas Udayana/RSUP Sanglah Denpasar. Waktu penelitian dilaksanakan selama 3 bulan, yaitu dari bulan April hingga Juni 2021.

Total sampel sebanyak 43 sampel yang dipilih dengan cara consecutive sampling yakni dengan pemilihan sampel dengan menetapkan subjek yang memenuhi kriteria penelitian. Selama periode penelitian 1 Januari 2018 sampai 31 Desember 2019 dari data pemeriksaan histopatologi diperoleh sampel adenokarsinoma kolorektal yang memenuhi kriteria penelitian sebanyak 55 pasien dan dipilih secara consecutive sampling sebanyak 43 pasien.

Ruang lingkup penelitian berupa gambaran mikroskopis penderita adenokarsinoma kolorektal yang dilakukan pemeriksaan histopatologi di Laboratorium Patologi Anatomi Fakultas Kedokteran Universitas Udayana/RSUP Sanglah Denpasar, didiagnosis ulang untuk mendapatkan sampel sesuai kriteria inklusi dan eksklusi, kemudian dilakukan pulasan imunohistokimia untuk menilai ekspresi BRAF V600E. Ekspresi BRAF V600E akan dihubungkan dengan kejadian metastasis dan derajat diferensiasi adenokarsinoma kolorektal.

Sampel penelitian adalah penderita adenokarsinoma kolorektal yang telah dilakukan pemeriksaan histopatologi di Laboratorium Patologi Anatomi Fakultas Kedokteran Universitas Udayana/RSUP Sanglah Denpasar periode 1 Januari 2018 sampai 31 Desember 2019 yang memenuhi kriteria inklusi dan eksklusi. Adapun kriteria inklusi penelitian ini, yaitu 1) blok parafin dari bahan operasi reseksi karsinoma kolorektal yang didiagnosis sebagai adenokarsinoma kolorektal melalui pemeriksaan histopatologi; 2) blok parafin dalam kondisi baik dan masih mengandung jaringan 
tumor yang cukup untuk dilakukan pemeriksaan imunohistokimia; 3) sampel memiliki data pemeriksaan radiologi rontgen thorax atau CT-scan thorax dan ultrasonography (USG) abdomen dan/atau hasil pemeriksaan sitologi (cairan paru atau abdomen). Kriteria eklusinya, yaitu 1) kasus adenokarsinoma kolorektal yang telah mendapatkan terapi tambahan berupa kemoterapi maupun radioterapi yang diperoleh melalui data formulir pemeriksaan histopatologi atau penelusuran rekam medis; dan 2) blok parafin rusak, berjamur, atau blok parafin tidak ditemukan. Derajat diferensiasi berdasarkan proporsi diferensiasi kelenjar yang ditemukan pada sampel penelitian, dikategorikan menjadi derajat diferensiasi rendah jika bentuk kelenjar $\geq 50 \%$. Derajat diferensiasi tinggi jika bentuk kelenjar < $50 \%{ }^{13}$

Ekspresi positif protein BRAF V600E pada pulasan imunohistokimia dievaluasi pada sampel menggunakan metode skoring yang telah digunakan pada penelitian sebelumnya. ${ }^{16}$ Pulasan yang dinilai positif hanyalah pulasan sitoplasma. ${ }^{16,17}$ Kriteria positif ditetapkan apabila sitoplasma terpulas difus dengan intensitas kuat pada lebih dari $75 \%$ sel tumor. Penilaian ekspresi BRAF V600E dilakukan oleh peneliti dan dua orang ahli Patologi Anatomi menggunakan mikroskop cahaya binokuler Olympus CX23 dengan pembesaran 40x, 100x, dan 400x yang dilakukan secara blind independent tanpa mengetahui data metastasis dan derajat diferensiasi pasien. Apabila terjadi perbedaan dalam penentuan ekspresi BRAF V600E di antara peneliti dan dua orang ahli Patologi Anatomi tersebut maka dilakukan kesepakatan bersama secara konsensus.

Data diolah dengan menggunakan Program Statistical Package for the Social Sciences (SPSS) versi 20 untuk Windows. Analisis deskriptif dilakukan pada data karakteristik sampel penelitian. Analisis Chi-Square berdasarkan tabel silang $2 \times 2$ untuk menganalisis hubungan antara ekspresi BRAF V600E dengan metastasis pada adenokarsinoma kolorektal dan hubungan antara ekspresi BRAF V600E dengan derajat diferensiasi pada adenokarsinoma kolorektal. Nilai batas kemaknaan (a) ditentukan pada

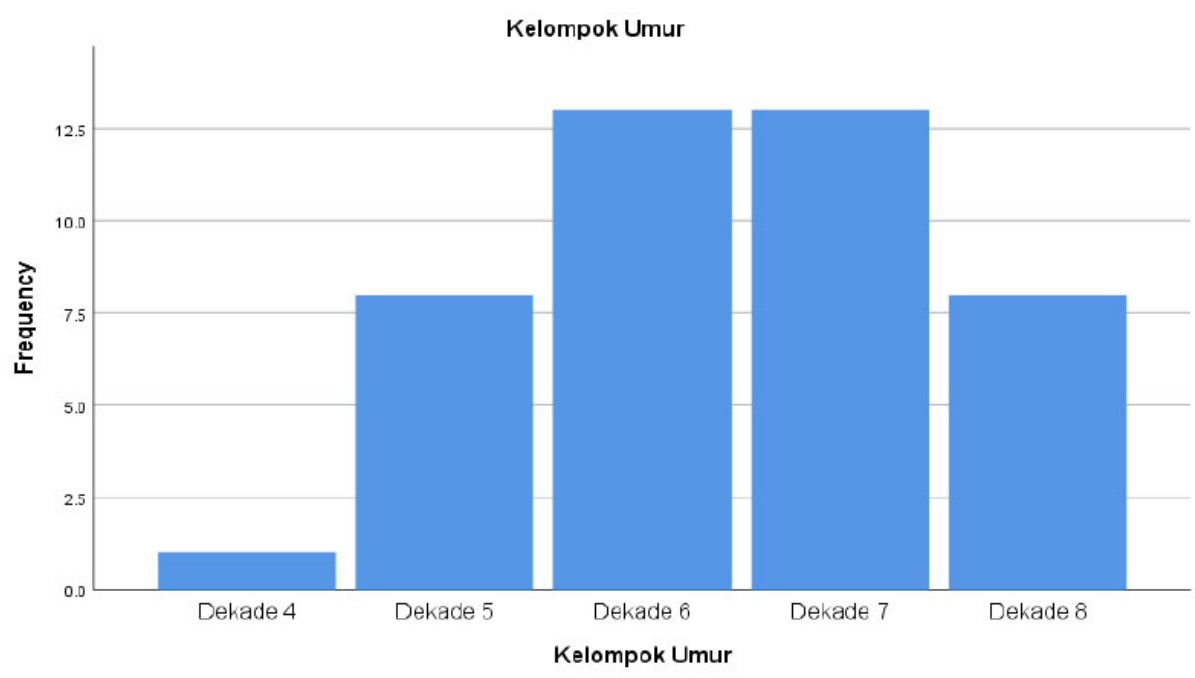

Gambar 1. Diagram batang distribusi KKR berdasarkan kelompok umur.

Tabel 1. Gambaran karakteristik sampel penelitian berdasarkan jenis kelamin, metastasis, dan derajat diferensiasi.

\begin{tabular}{lcc} 
Karakteristik sampel & Frekuensi & Persentase (\%) \\
\hline Jenis Kelamin & 30 & 69,8 \\
Laki-laki & 13 & 30,2 \\
$\quad$ Perempuan & & \\
Metastasis & 25 & 58,1 \\
$\quad$ Positif & 18 & 41,9 \\
$\quad$ Negatif & & \\
Derajat Diferensiasi & 8 & 18,6 \\
Tinggi & 35 & 81,4 \\
$\quad$ Rendah & & \\
Lokasi Metastasis & 18 & 72,0 \\
Paru-Paru & 6 & 24,0 \\
Hepar & 1 & 4,0 \\
Hepar dan Paru-Paru & & \\
\hline
\end{tabular}

probabilitas $(\mathrm{p})<0,05$.

\section{HASIL}

Berdasarkan variabel usia didapatkan usia termuda 33 tahun dan usia tertua 80 tahun, usia rata-rata $60,28 \pm 10,944$ tahun. Setelah dikelompokkan berdasarkan dekade usia, maka didapatkan kasus terbanyak pada dekade ke enam dan ke tujuh (Gambar 1) yaitu masing-masing sebanyak 13 kasus $(30,2 \%)$. Gambaran karakteristik sampel penelitian lainnya disajikan pada Tabel 1. Berdasarkan parameter metastasis, distribusi lokasi metastasis yaitu pada paru-paru sebanyak 18 kasus (72,0\%), hepar sebanyak 6 kasus $(24,0 \%)$ serta ke hepar dan paru-paru sebanyak 1 kasus $(4,0 \%)$ (Tabel 1).
Pada penelitian ini menunjukkan ekspresi BRAF V600E positif sebanyak 7 (16,3\%) kasus serta ekspresi BRAF V600E negatif sebanyak 36 (83,7\%) kasus. Pulasan imunohistokimia BRAF V600E positif dan negatif disajikan pada Gambar 2 dan 3.

Berdasarkan parameter metastasis, distribusi lokasi metastasis yaitu pada paru-paru sebanyak 18 kasus (72,0\%), hepar sebanyak 6 kasus $(24,0 \%)$ serta ke hepar dan paru-paru sebanyak 1 kasus $(4,0 \%)$ (Tabel 1).

Ekspresi BRAF V600E positif tidak ditemukan pada kasus derajat diferensiasi tinggi dan 7 (100\%) kasus derajat diferensiasi rendah. Sementara ekspresi BRAF V600E negatif ditemukan pada 8 $(22,2 \%)$ kasus derajat diferensiasi tinggi 
dan $28(77,8)$ kasus derajat diferensiasi rendah (Tabel 2). Hasil analisis Chi-Square pada Tabel 2 didapatkan nilai $\mathrm{p}=0,167$ yang menunjukkan tidak terdapat hubungan yang bermakna secara statistik antara ekspresi BRAF dengan derajat diferensiasi pada adenokarsinoma kolorektal.

Semua kasus ekspresi BRAF V600E positif (100\%) menunjukkan metastasis positif. Sementara kasus dengan ekspresi
BRAF negatif, 18 kasus (50\%) dengan metastasis positif dan 18 kasus (50\%) dengan metastasis negatif (Tabel 3). Terdapat hubungan yang bermakna secara statistik antara ekspresi BRAF V600E dengan metastasis pada adenokarsinoma kolorektal $(\mathrm{p}=0,014)$.

Pada kasus dengan derajat diferensiasi tinggi, 25\% menjadi metastasis positif sementara kasus dengan derajat
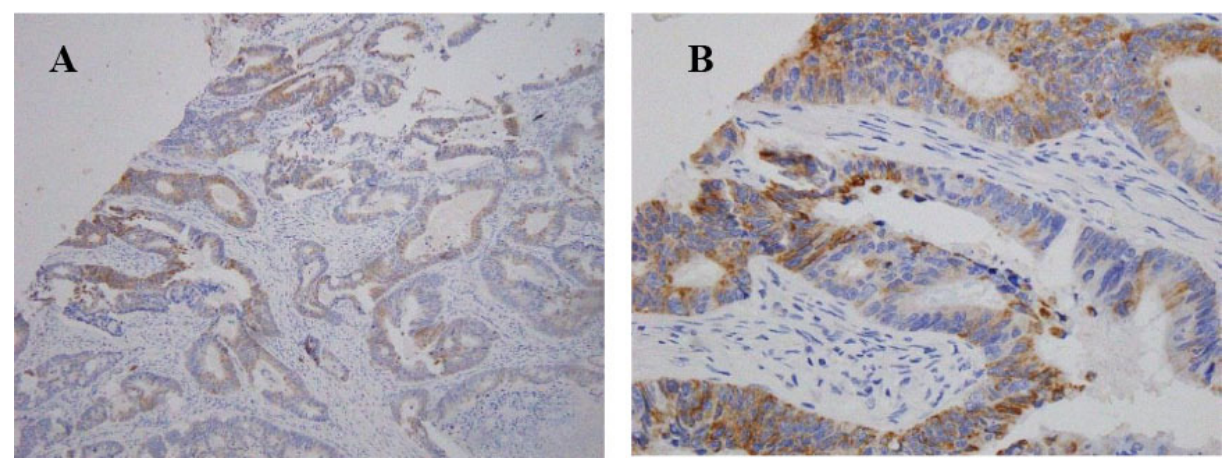

Gambar 2. Pulasan imunohistokimia BRAF V600E positif. (A) Pembesaran 100x dan (B) Pembesaran 400x.
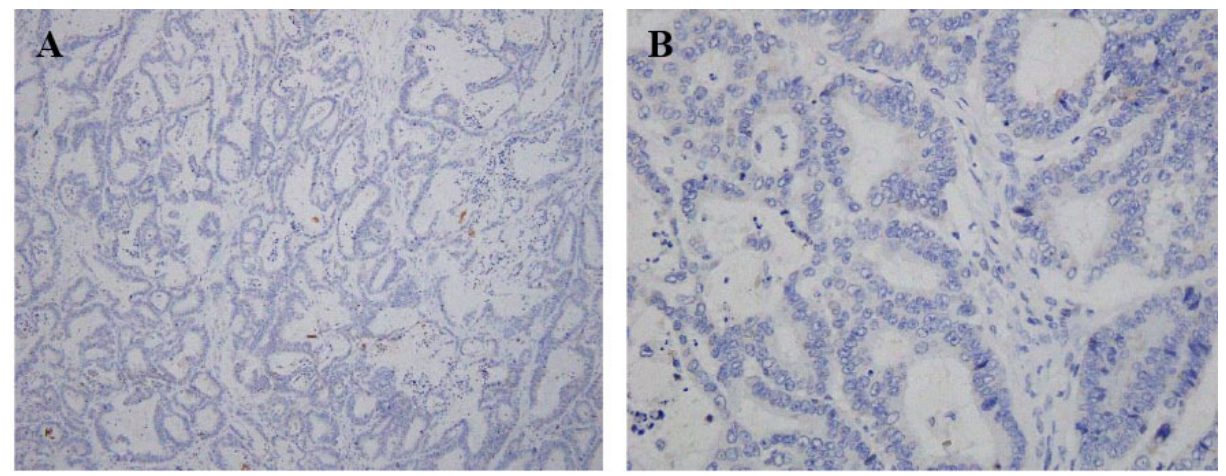

Gambar 3. Pulasan imunohistokimia BRAF V600E negatif. (A) Pembesaran 100x dan (B) Pembesaran 400x.

Tabel 2. Hubungan antara ekspresi BRAF V600E dengan derajat diferensiasi.

\begin{tabular}{|c|c|c|c|c|c|}
\hline \multirow{2}{*}{\multicolumn{2}{|c|}{ Parameter }} & \multicolumn{2}{|c|}{ Derajat diferensiasi $(\mathrm{N}=43)$} & \multirow{2}{*}{ Total (\%) } & \multirow{2}{*}{$\mathbf{p}$} \\
\hline & & Tinggi $(\mathbf{N}=\mathbf{8})$ & Rendah ( $\mathrm{N}=35)$ & & \\
\hline \multirow[t]{2}{*}{ Ekspresi BRAF, n (\%) } & Positif & $0(0,0)$ & $7(100,0)$ & $7(100,0)$ & $0,167^{\star}$ \\
\hline & Negatif & $8(22,2)$ & $28(77,8)$ & $36(100,0)$ & \\
\hline
\end{tabular}

${ }^{\star}$ Chi-Square: secara statistik bermakna apabila nilai $\mathrm{p}<0,05$.

Tabel 3. Hubungan antara ekspresi BRAF V600E dengan metastasis dan derajat diferensiasi.

\begin{tabular}{|c|c|c|c|c|c|}
\hline \multicolumn{2}{|c|}{ Parameter } & \multicolumn{2}{|c|}{ Metastasis $(\mathrm{N}=43)$} & \multirow{2}{*}{ Total (\%) } & \multirow{2}{*}{$\mathbf{p}$} \\
\hline & & Positif ( $\mathrm{N}=25$ ) & Negatif $(\mathrm{N}=18)$ & & \\
\hline \multirow[t]{2}{*}{ Ekspresi BRAF, n (\%) } & Positif & $7(100,0)$ & $0(0,0)$ & $7(100,0)$ & $0,014^{*}$ \\
\hline & Negatif & $18(50,0)$ & $18(50,0)$ & $36(100,0)$ & \\
\hline \multirow[t]{2}{*}{ Derajat Diferensiasi, n (\%) } & Tinggi & $2(25,0)$ & $6(75,0)$ & $8(100,0)$ & $0,035^{\star}$ \\
\hline & Rendah & $23(65,7)$ & $12(34,3)$ & $35(100,0)$ & \\
\hline
\end{tabular}

${ }^{\star}$ Chi-Square: secara statistik bermakna apabila nilai $\mathrm{p}<0,05$. 
laki-laki daripada perempuan (2,3:1).

Sebanyak $4,4 \%$ kasus KKR menunjukkan adanya mutasi BRAF, terutama mutasi V600E pada ekson $15 .{ }^{23}$ Studi yang dilakukan oleh Ritterhouse LL dan Barletta JA, pada tahun 2015 menunjukkan mutasi BRAF V600E terjadi pada kurang lebih $10-15 \%$ pasien KKR. ${ }^{7}$ Mutasi BRAF dapat dijumpai pada $7-10 \%$ pasien KKR metastasis, $60 \%$ MSI high tumors dan hanya 5-10\% tumor microsatellite stable (MSS). ${ }^{6,12}$

Menurut studi yang dilakukan oleh Kwon JH et al, pada tahun 2018, IHK BRAF V600E dapat dipergunakan untuk mendeteksi mutasi BRAF V600E. ${ }^{17}$ Hernowo BS et al., pada tahun 2014 yang melakukan studi di Rumah Sakit Hasan Sadikin, Bandung menyimpulkan bahwa hasil pewarnaan imunohistokimia BRAF V600E dapat dipakai sebagai penanda KKR yang lebih agresif. ${ }^{24}$ Hasil tersebut sejalan dengan penelitian ini yang mendapatkan hasil ekspresi positif BRAF V600E pada $16,3 \%$ kasus.

Studi metaanalisis oleh Wang $\mathrm{J}$ et al., tahun 2019 yang menggunakan 20 penelitian untuk menilai hubungan antara mutasi BRAF V600E dengan derajat diferensiasi tumor didapatkan hasil pada 7,81\% kasus dengan derajat diferensiasi baik hingga sedang menunjukkan adanya mutasi BRAF serta 26,34\% kasus dengan derajat diferensiasi buruk menunjukkan adanya mutasi BRAF. ${ }^{25}$ Berbeda dengan hasil penelitian yang dilakukan oleh Vilkin A et al., tahun 2009 dan Rako I et al., tahun 2012 mendapatkan hasil bahwa tidak terdapat hubungan yang bermakna antara ekspresi BRAF V600E dengan derajat diferensiasi. ${ }^{26,27}$ Hasil penelitian tersebut sejalan dengan hasil penelitian kami, dimana hasil ekspresi BRAF V600E positif tidak ditemukan pada kasus dengan derajat diferensiasi tinggi dan $7(100 \%)$ kasus derajat diferensiasi rendah. Sementara ekspresi BRAF negatif ditemukan pada $8(22,2 \%)$ kasus derajat diferensiasi tinggi dan $28(77,8 \%)$ kasus derajat diferensiasi rendah. Tidak terdapat hubungan yang bermakna antara ekspresi BRAF V600E dengan derajat diferensiasi pada adenokarsinoma kolorektal dapat disebabkan oleh perbedaan jumlah sampel.

Penelitian ini mendapatkan hasil ekspresi BRAF V600E positif ditemukan pada 7 kasus metastasis positif dan 0 kasus metastasis negatif. Sementara ekspresi BRAF negatif ditemukan pada $50 \%$ kasus metastasis positif dan 50\% kasus metastasis negatif. Dari analisis Chi-Square dapat disimpulkan terdapat hubungan yang bermakna secara statistik antara ekspresi BRAF V600E dengan metastasis pada KKR. Hal ini sejalan dengan penelitian yang dilakukan oleh Kwon JH et al., pada tahun 2018. Penelitian tersebut mendapatkan hasil metastasis jauh baik unifokal maupun multifokal berhubungan dengan mutasi BRAF V600E $(\mathrm{p}<0,001) .{ }^{17}$ Studi lainnya yang dilakukan oleh Saridaki $\mathrm{Z}$ et al., tahun 2013 yang menganalisis hubungan antara jumlah lokasi metastasis dengan mutasi pada BRAF V600E pada kasus metastasis KKR, didapatkan hasil bahwa mutasi pada BRAF berhubungan dengan metastasis lebih dari 1 lokasi $(\mathrm{p}=0,002) .{ }^{28} \mathrm{Hal}$ tersebut menunjukkan bahwa adanya mutasi pada BRAF V600E, yang salah satunya ditandai dengan ekspresi positif pada pemeriksaan IHK merupakan faktor krusial pada terjadinya dan perkembangan dari KKR. Namun, masih terdapat 18 kasus dengan status ekspresi BRAF V600E negatif. Hal ini dapat disebabkan oleh mutasi BRAF yang terjadi tidak hanya pada V600E saja. Mutasi BRAF yang lain memegang peranan dalam menentukan status metastasis walaupun dalam persentase yang lebih kecil dibandingkan V600E. ${ }^{29}$ Selain mutasi BRAF, prognosis buruk penyakit KKR juga dapat ditentukan dari status molekuler mutasi MSI dan CIMP. ${ }^{29}$ Hal ini memerlukan penelitian lebih lanjut yang meneliti kondisi mutasi lainnya yang dapat menyebabkan metastasis positif antara lain status mutasi KRAS serta MMR DNA (MSI/MSS dan CIMP).

Ketika dilakukan analisis hubungan antara derajat diferensiasi dengan metastasis ditemukan adanya hubungan yang bermakna secara statistik antara derajat diferensiasi dengan metastasis pada adenokarsinoma kolorektal $(\mathrm{p}=0,035)$. Hal tersebut sesuai dengan penelitian yang dilakukan oleh Minhajat $\mathrm{R}$ et al., pada tahun 2020. ${ }^{30}$ Terdapat hubungan bermakna antara diferensiasi adenokarsinoma kolorektal dengan metastasis $(\mathrm{p}<0,0001)$. Metastasis jauh ditemukan pada sebagian besar (62\%) adenokarsinoma diferensiasi buruk, sementara pada sebagian besar kasus $(73,2 \%)$ adenokarsinoma diferensiasi baik tidak terdapat metastasis. Hubungan antara derajat diferensiasi dengan metastasis pada KKR dapat disebabkan oleh adanya peningkatan aktivitas mitosis dan hiperproliferasi sel ganas pada KKR dengan diferensiasi buruk. ${ }^{30}$

\section{SIMPULAN}

Tidak terdapat hubungan antara ekspresi BRAF V600E dengan derajat diferensiasi pada adenokarsinoma kolorektal di RSUP Sanglah Denpasar. Terdapat hubungan antara ekspresi BRAF V600E dengan metastasis pada adenokarsinoma kolorektal di RSUP Sanglah Denpasar. Diperlukan penelitian lebih lanjut untuk mendeteksi peran molekul lain, seperti MSI/MSS, KRAS serta CIMP untuk mendapatkan informasi lebih lengkap dalam memprediksi hasil klinis KKR.

\section{KONFLIK KEPENTINGAN}

Penulis menyatakan tidak terdapat konflik kepentingan terkait publikasi dari penelitian ini.

\section{ETIKA PENELITIAN}

Penelitian ini telah mendapatkan persetujuan dari Komite Etik Fakultas Kedokteran Universitas Udayana/RSUP Sanglah Denpasar dengan No. 821/UN 14.2.2.VII.14/LT/2021.

\section{PENDANAAN}

Penelitian ini tidak mendapatkan bantuan dana hibah dari pemerintah maupun sektor swasta lainnya.

\section{KONTRIBUSI PENULIS}

Seluruh penulis memiliki kontribusi yang sama dalam penulisan artikel penelitian ini baik dari tahap pengumpulan data, analisis data penelitian, hingga laporan hasil penelitian.

\section{DAFTAR PUSTAKA}

1. Fredericks E, Dealtry G, Roux S. Molecular aspects of Colorectal Carcinogenesis: A Review. J Cancer Biol Re. 2015;3(1):1057. 
2. Jemal A, Bray F, Center MM, Ferlay J, Ward E, Forman D. Global cancer statistics. CA Cancer J Clin. 2011;61(2):69-90.

3. Caputo F, Santini C, Bardasi C, Cerma K, Casadei-Gardini A, Spallanzani A, et al. BRAF-Mutated Colorectal Cancer: Clinical and Molecular Insights. Int $\mathrm{J}$ Mol Sci. 2019;20(21):5369.

4. Siegel RL, Miller KD, Fedewa SA, Ahnen DJ, Meester RGS, Barzi A, et al. Colorectal cancer statistics, 2017. CA Cancer J Clin. 2017;67(3):177-193.

5. Wiranata S, Anjani IAW, Saputra IPGS, Sadvika IGAS, Prabawa IPY, Supadmanaba IG, et al. Pretreatment Neutrophil-to-Lymphocyte Ratio and Platelet-to-Lymphocyte Ratio as a Stage Determination in Breast Cancer. Open Access Maced J Med Sci. 2020;8(B):1058-1063.

6. Luu LJ, Price TJ. BRAF mutation and its importance in colorectal cancer. Intech Open. 2019:1-18.

7. Ritterhouse LL, Barletta JA. BRAF V600E mutation-specific antibody: A review. Semin Diagn Pathol. 2015;32(5):400-408.

8. Loupakis F, Intini R, Cremolini C, Orlandi A, Sartore-Bianchi A, Pietrantonio F, et al. A validated prognostic classifier for ${ }^{\mathrm{V} 600 \mathrm{~B}} \mathrm{BRAF}-$ mutated metastatic colorectal cancer: the 'BRAF BeCool' study. Eur J Cancer. 2019;118:121-130.

9. Zhang $\mathrm{X}, \mathrm{Wu}$ J, Wang L, Zhao H, Li H, Duan $Y$, et al. HER2 and BRAFmutation in colorectal cancer patients: a retrospective study in Eastern China. PeerJ. 2020;8:e8602.

10. Wang X, Wei Q, Gao J, Li J, Li J, Gong J, et al. Clinicopathologic features and treatment efficacy of Chinese patients with BRAFmutated metastatic colorectal cancer: a retrospective observational study. Chin J Cancer. 2017;36(1):81.

11. Manne U, Shanmugam C, Katkoori VR, Bumpers HL, Grizzle WE. Development and progression of colorectal neoplasia. Cancer Biomark. 2010;9(1-6):235-265.

12. Clarke CN, Kopetz ES. BRAF mutant colorectal cancer as a distinct subset of colorectal cancer: clinical characteristics, clinical behavior, and response to targeted therapies. J Gastrointest Oncol. 2015;6(6):660-667.

13. Dean TM. Carcinoma of the colon and rectum. A perspective for practicing physicians, with recommendations for screening. West J Med. 1977;126(6):431-440.

14. Fleming M, Ravula S, Tatishchev SF, Wang HL. Colorectal carcinoma: Pathologic aspects. J Gastrointest Oncol. 2012;3(3):153-173.

15. Marzouk O, Schofield J. Review of histopathological and molecular prognostic features in colorectal cancer. Cancers (Basel). 2011;3(2):2767-2810.

16. Toon CW, Walsh MD, Chou A, Capper D, Clarkson A, Sioson L, et al. BRAFV600E immunohistochemistry facilitates universal screening of colorectal cancers for Lynch syndrome. Am J Surg Pathol. 2013;37(10):15921602.

17. Kwon JH, Jeong BK, Yoon YS, Yu CS, Kim J. Utility of BRAF VE1 Immunohistochemistry as a Screening Tool for Colorectal Cancer Harboring BRAF V600E Mutation. J Pathol Transl Med. 2018;52(3):157-163.

18. Haraldsdottir S, Einarsdottir HM, Smaradottir A, Gunnlaugsson A, Halfdanarson TR. Colorectal cancer - review. Laeknabladid. 2014;100(2):75-82.

19. Rawla P, Sunkara T, Barsouk A. Epidemiology of colorectal cancer: incidence, mortality, survival, and risk factors. Prz Gastroenterol. 2019;14(2):89-103.

20. Siegel RL, Miller KD, Goding Sauer A, Fedewa SA, Butterly LF, Anderson JC, et al. Colorectal cancer statistics, 2020. CA Cancer J Clin. 2020;70(3):145-164.

21. Wong MC, Ding H, Wang J, Chan PS, Huang J. Prevalence and risk factors of colorectal cancer in Asia. Intest Res. 2019;17(3):317-329.

22. Putranto AS, Julistian J. Risk Factors of Colorectal Carcinoma Incidence in Young Adults: A Meta-analysis. The New Ropanasuri Journal of Surgery. 2019;4(1):1-6.
23. Dewi NNA, Sumadi IWJ, Sun HS. Molecular Profile of Colorectal Cancer Patients in Bali Based On Methylation Of $\mathrm{O}^{6}$-Methylguanine DNA Methyltransferase Promoter Region and Mutation of BRAF and Kirsten Rat Sarcoma Viral Oncogene Homolog Gene. J Med Sci. 2020;20(10):1-8.

24. Hernowo BS, Ariyanni F, Suryanti S, Hassan $\mathrm{AH}$. Use of BRAF V600E as a molecular marker in aggressive colorectal cancer. Acta Med Indones. 2014;46(2):104-110.

25. Wang J, Shen J, Huang C, Cao M, Shen L. Clinicopathological Significance of BRAFV600E Mutation in Colorectal Cancer: An Updated Meta-Analysis. J Cancer. 2019;10(10):2332-2341.

26. Vilkin A, Niv Y, Nagasaka T, Morgenstern S, Levi Z, Fireman Z, et al. Microsatellite instability, MLH1 promoter methylation, and BRAF mutation analysis in sporadic colorectal cancers of different ethnic groups in Israel. Cancer. 2009;115(4):760-9.

27. Rako I, Jakic-Razumovic J, Katalinic D, Sertic J, Plestina S. Mutation pattern of KRAS and BRAF oncogenes in colorectal cancer patients. Neoplasma. 2012;59(4):376-383.

28. Saridaki Z, Tzardi M, Sfakianaki M, Papadaki C, Voutsina A, Kalykaki A, et al. BRAFV600E mutation analysis in patients with metastatic colorectal cancer (mCRC) in daily clinical practice: correlations with clinical characteristics, and its impact on patients' outcome. PLoS One. 2013;8(12):e84604.

29. Inamura K. Colorectal Cancers: An Update on Their Molecular Pathology. Cancers (Basel). 2018;10(1):26.

30. Minhajat R, Benyamin AF, Miskad UA. The Relationship Between Histopathological Grading and Metastasis in Colorectal Carcinoma Patients. 2020;5(2):51-60.

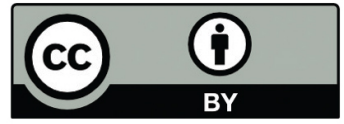

This work is licensed under a Creative Commons Attribution 